\title{
Effect of some Pre- and Postharvest Treatments on the Ability of "Balady" Orange Fruits to Storage
}

\author{
El-Mahdy, T.K.; A.M.A. El-Sese; "Maha M. Abdel-Salam and Fatma A. Ismail \\ Pomology Department, Assiut University, Assiut, Egypt, Box. 71526 \\ *Emai1: maha.hussien@agr.au.edu.eg
}

Received on: $29 / 5 / 2017$

Accepted for publication on: 6/6/2017

\begin{abstract}
:
The experiment was conducted during two successive seasons (2015 and 2016) on Balady orange trees (Citrus sinensis) which divided in two groups. The first group was sprayed with potassium sulphate $(48 \%)$ in the orchard at three times sequential (March, June and August) and the second group was sprayed with water (control). Orange fruits of both treatments were collected in maturity stage and dipped in salicylic acid (SA) at $4 \mathrm{mM} / 1$ in laboratory. The purpose of this investigation is studying the effect of SA and $\mathrm{K}$ on orange fruits quality during storage at room temperature $\left(13+2 \mathrm{C}^{\circ}\right)$. Some physical and chemical properties of fruits were estimated every 10 days till 50 days (the end of storage) such as weight loss $\%$, juice content $\%$, acidity $\%$, total soluble solids $\%$ (TSS), TSS/ acid ratio and ascorbic acid during both seasons. The results illustrated that, SA had a positive effect on fruit quality of the fruits treated with SA single or combined with potassium sulphate.
\end{abstract}

Keywords: Balady orange(Citrus sinensis) -salicylic acid - potassium sulphate.

Introduction:

Citrus are considered an important fruits in many parts of the world because it has a high nutritional values of vitamins, essential oils, minerals, sugarsand salts. In general, citrus fruits especially sweet orange (Citrus sinensis L.) are an important fruit crop of Egypt. It is grown on an area of 23057 feddans and produced about146469 tones (FAO, 2014). Orange is considered as a main source of antioxidants like vitamin $\mathrm{C}$, phenolic compounds and carotenoids, so it has an important functions in resistance against many human illnesses (Del Caro et al., 2004); (DhuiqueMayer et al., 2005) and (Wu et al., 2007).

Edible coatings are used on vegetables and fruits to improve appearance, modifying atmosphere around fruit's surface to reduce fruit respiration rate of fruit and improve the environmental conditions like humidity and temperature (Baldwin et al., 1995). These conditions providing a semi permeable barrier for enhancing carbon dioxide rates and reducing oxygen rates and therefor reducing respiration retard the ripening, reducing decay and water loss, decrement the oxidation reaction rates and metabolic activities, especially transpiration and respiration. So, coating fruits becomes more resistance to pathogens and promoting their marketing and storage (Petracek et al., 1998), (Park, 1999) and (Chitarra and Chitarra, 2005).

The low temperature is one of the most efficient methods to improve the storage life and prolong the shelf life of fresh food product (Shein et $a l ., 2008)$. It is the main way to extend the storage life, however, there 
are other means to improve the storage life.

Salicylic acid (SA) or Orthohydroxy benzoic acid was found at different concentrations in horticultural crops. It is a simple phenolic compound with a phytohormone-like function as plant growth and development because of its effects on plant physiological processes and it enhances plant vigour under biotic and abiotic stresses (Scotter et al., 2007), (Hayat et al., 2010). There are many important functions of SA such as delaying ripen and senescence of fruits by stimulating the accumulation of biologically active compounds and antioxidant enzymes such as catalase (CAT), peroxidase (POD) and superoxide dismutase (SOD) leading to a reduce in free radical levels and lipid peroxidation (Huang et al., 2008), reducing fruit softening rate, inhibiting ethylene biosynthesis and action by preventing the conversion of ACC into ethylene and suppressing ACC oxides' activity thereby, it causes the delay of fruit ripening (Zhang et al., 2003). It also increases the resistance of chilling injury, accumulation of phenolic compounds and prolonging storage life of fruits (Srivastava and Dwivedi, 2000), (Zhang et al., 2003), (Chen et al., 2006).

Potassium is also important in formation and functioning of proteins, fats, carbohydrates and chlorophyll and in maintaining the balance of salts and water in plant cells, (Achilea, 1998). Heavy citrus orchards should receive considerable amount of $\mathrm{K}$, nearly at the same level as nitrogen, in order to preserve high yields of fruits with the required qualities. The relatively high acid level caused by application of $\mathrm{K}$ can be qualified, in most cases, by briefly delaying the harvest. The physiological functions of potassium and its conspicuous role in plant water relations has long been known and serve to emphasize that there should be adequate $\mathrm{K}$ contents in all plant parts (Hsiao and Lauchli, 1986).

The aim of this research is achieving the following specific objectives;

1. Prolonging the storage period of orange fruits with retention the highest quality of marketing and consumables with the lowest cost.

2. Studying the effect of salicylic acid and potassium on physical and chemical properties and the quality of fruits during storage.

\section{Materials and Methods:}

This investigation was conducted on Balady orange (Citrus sinensis) during two successive seasons 2015 and 2016 at the orchard and laboratory of Pomology department, Faculty of Agriculture, Assiut University. Twenty trees were healthy, uniform in vigor as possible were chosen for achieving this study. All trees received the standard agricultural practices that are used in the orchard including soil fertilization, irrigation and pest control. The selected 20 trees were divided into two groups, the first group was sprayed with potassium sulphate $(48 \%)$ at three times individually and sequentially (March, June and August) and the second group was sprayed with water (control). Orange fruits of both groups were collected at maturity stage (index -MI, calculated as SSC/TA ratio, was 8.3). The fruits were selected for uniformity of shape, 
size, color and free of physical damage and infections. The fruits were washed by distilled water and then dipped in a $500 \mathrm{ppm}$ binomial solution after that left in air for about 20 mins until dry and then fruits were immersed in SA (4 mM/l) for 3 mins. The fruits were randomly divided into four treatments with 3 replicates (each replicate had 6 fruits) as follow:-

- Control (untreated) $\left(\mathbf{T}_{1}\right)$

- Potassium Sulphate (48\%) $\left(\mathbf{T}_{2}\right)$

- Salicylic acid(SA) 4mM/l ( $\left.\mathbf{T}_{3}\right)$

- Potassium Sulphate (48\%) and SA $\left(\mathbf{T}_{4}\right)$

Ten fruits of each treatment were numbered and used for weight loss determination.

*(SA was prepared, by dissolving SA powder in hot distilled water or ethanol alcohol then completed to liter of distilled water).

The fruits were placed in layersin a carton boxes and stored in room temperature at $13 \pm 2 \mathrm{C}^{\circ}$. Fruits were evaluated through the following determinations every 10 days until 50 days (the end of storage).

\section{1-Weight loss (\%):}

Weight of fresh fruit (g) - Weight after interval (g) X 100 Weight of fresh fruits $(\mathrm{g})$

*Interval $=10$ days

\section{2-Fruit juice content $\%$ :}

Weight of extracted juice X 100 Fruit weight

3-Total soluble solid (T.S.S): A hand refractometer was used to determine the soluble solids content in fruit juice according to (AOAC 1990).

4-Total acidity\%: Total acidity was measured by titrating $5 \mathrm{ml}$ juice on $0.1 \mathrm{~N} \mathrm{NaOH}$ solution and was then determined as the percent age of citric acid (Equation 2).

Citric acid $(\%)=$

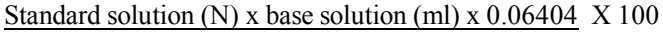
Total juice volume (ml)
*The equivalent weight of citric acid $=0.06404$ *juice volume $=5 \mathrm{ml}$

5-TSS/Acid ratio: $=\quad$ TSS Total Acid contents

6-Percentage of reducing sugars in the juice according to Lane and Eynon procedure which was outlined in AOAC., (1985).

7-Ascorbic acid content (mg/100ml) Ascorbic acid was determined by using 2.6 dichloro phenol indophenol dye method AOAC, (1990), ten ${ }_{g}$ of the fresh sample was blended with 3\% metaphosphoric acetic acid extracting solution to homogenous slurry, then $5 \mathrm{ml}$ of the filtrate extract were then titrated with standard indophenols until reached to pink end point.

\section{Statistical analysis}

This experiment was set up as split plot design. The storage treatments were in the whole plots $(\mathrm{T})$, while the storage period were insub.plots (p). All data were tabulated and statistically analyzed according to (Snedecor and Cochran, 1989) using L.S.D at 0.05 levels for comparison between various treatment means.

\section{Results}

\section{A- Physical properties:}

1- Weight loss \%:

The obtained results in Table 1 proved that the weight loss $\%$ significantly increased with the prolonging of storage period in the two successive seasons. Data illustrated that there were significant differences between control with treatments and within treatments too during storage. At the end of storage the highest value of weight $\operatorname{loss} \%$ was found in control fruit (29.33 and 28.33\%) while the lowest value was recorded by SA treatment (22.20 and 23.53\%) in the two seasons, respectively. Data 
proved that the best treatment which included with SA, gave the best effect to prevent the fruits from loss their weight.

Our results are in agreement with (Goepfert et al., 1987), (Gill et al., 2005), (Hafez and Haggag, 2007), (Ali et al, 2010), (Sakhale and Kapse, 2012).

\section{2- Juice content \%:}

Data presented in Table 2 reveded that there was a gradual and significant reduction of juice content $\%$ in Balady orange fruit with progress the storage period during both investigated seasons. At the end of storage period the lowest value of juice content $\%$ were found in the untreated fruits (33.17 and 40.10\%) during 2015 and 2016 seasons, respectively.
In addition the highest juice percentage at the end of storge time were recorded in orange fruits treated with SA+K (43.43 and $45.20 \%)$ followed by SA alone (43.30 and 42.63 $\%$ ) during both tested seasons, respectively.

These results are in agreement with those obtained by (Hafez and Haggag, 2007) (Ali et al, 2010) and (Sakhale and Kapse, 2012). The effect of potassium on increasing juice volume of citrus fruits was reported by (Lavon et al., 1995) in Star- Ruby grapefruit; and (Maksoud et al., 2003) in Balady mandarin trees; (Miller et al., 1998) reported that spraying of potassium fertilizers gave no significant effect on Midknight Valencia and Robyn Navel fruit quality including juice content.

Table 1. Effect of potassium sulphate $(48 \%)$ and salicylic acid $(4 \mathrm{mM} / \mathrm{l})$ on weight loss \% during storage periodat room temperature $\left(13 \pm 2 \mathrm{C}^{\circ}\right)$ on "Balady" orange fruits during 2015 and 2016 seasons

\begin{tabular}{|c|c|c|c|c|c|c|c|c|c|c|c|}
\hline \multicolumn{6}{|c|}{ Season 2015} & \multicolumn{6}{|c|}{ Season 2016} \\
\hline \multirow[t]{2}{*}{ Period } & \multicolumn{4}{|c|}{ Treatments } & \multirow{2}{*}{ Mean } & \multirow{2}{*}{ Period } & \multicolumn{4}{|c|}{ Treatments } & \multirow{2}{*}{ Mean } \\
\hline & Control & $\mathrm{K}$ & SA & $\mathrm{SA}+\mathrm{K}$ & & & Control & $\mathrm{K}$ & SA & $\mathrm{SA}+\mathrm{K}$ & \\
\hline 0 date & 0.00 & 0.00 & 0.00 & 0.00 & 0.00 & 0 date & 0.00 & 0.00 & 0.00 & 0.00 & 0.00 \\
\hline 10 days & 11.53 & 13.10 & 8.90 & 9.47 & 10.75 & 10 days & 9.33 & 9.68 & 7.80 & 8.00 & 8.70 \\
\hline 20 days & 15.93 & 17.17 & 13.33 & 13.43 & 14.97 & 20 days & 16.00 & 16.63 & 14.23 & 14.43 & 15.33 \\
\hline 30 days & 20.83 & 20.93 & 17.60 & 17.30 & 19.17 & 30 days & 20.20 & 20.40 & 17.80 & 18.03 & 19.11 \\
\hline 40 days & 23.70 & 23.57 & 19.67 & 20.33 & 21.82 & 40 days & 23.07 & 22.93 & 20.73 & 21.20 & 21.98 \\
\hline 50 days & 29.33 & 28.50 & 22.20 & 22.93 & 25.74 & 50 days & 28.33 & 27.83 & 23.53 & 24.10 & 25.95 \\
\hline Mean & 16.89 & 17.21 & 13.62 & 13.91 & & Mean & 16.16 & 16.25 & 14.02 & 14.29 & \\
\hline \multicolumn{4}{|c|}{ L.S.D $0.05 \mathrm{~A}($ Treatments $)=$} & \multicolumn{2}{|c|}{0.49} & \multicolumn{4}{|c|}{ L.S.D $0.05 \mathrm{~A}($ Treatments $)=$} & \multicolumn{2}{|c|}{0.39} \\
\hline \multicolumn{4}{|c|}{ L.S.D 0.05 B(Period $)=$} & \multicolumn{2}{|c|}{0.59} & \multicolumn{4}{|c|}{ L.S.D $0.05 \mathrm{~B}($ Period $)=$} & \multicolumn{2}{|c|}{0.48} \\
\hline \multicolumn{4}{|c|}{ L.S.D $0.05 \mathrm{AB}=$} & \multicolumn{2}{|c|}{1.19} & \multicolumn{4}{|c|}{ L.S.D $0.05 \mathrm{AB}=$} & \multicolumn{2}{|c|}{0.96} \\
\hline
\end{tabular}


Table 2. Effect of potassium sulphate $(48 \%)$ and salicylic acid $(4 \mathrm{mM} / \mathrm{l})$ on juice content \% during storage period at room temperature $\left(13 \pm 2 \mathrm{C}^{\circ}\right)$ on "Balady" orange fruits during 2015 and 2016 seasons

\begin{tabular}{|c|c|c|c|c|c|c|c|c|c|c|c|}
\hline \multicolumn{6}{|c|}{ Season 2015} & \multicolumn{6}{|c|}{ Season 2016} \\
\hline \multirow{2}{*}{ Period } & \multicolumn{4}{|c|}{ Treatments } & \multirow{2}{*}{ Mean } & \multirow{2}{*}{ Period } & \multicolumn{4}{|c|}{ Treatments } & \multirow{2}{*}{ Mean } \\
\hline & Control & $\mathrm{K}$ & SA & $\mathrm{SA}+\mathrm{K}$ & & & Control & $\mathrm{K}$ & SA & $\mathrm{SA}+\mathrm{K}$ & \\
\hline 0 date & 51.80 & 54.43 & 51.80 & 54.43 & 53.12 & 0 date & 54.50 & 55.47 & 54.50 & 55.47 & 54.98 \\
\hline 10 days & 47.80 & 50.37 & 50.27 & 51.27 & 49.93 & 10 days & 50.80 & 52.17 & 52.90 & 53.60 & 52.37 \\
\hline 20 days & 43.50 & 46.27 & 48.00 & 49.03 & 46.70 & 20 days & 47.43 & 47.67 & 49.53 & 51.33 & 48.99 \\
\hline 30 days & 39.77 & 42.13 & 46.30 & 46.50 & 43.68 & 30 days & 43.77 & 43.47 & 47.20 & 49.27 & 45.93 \\
\hline 40 days & 35.87 & 38.27 & 45.03 & 45.30 & 41.12 & 40 days & 42.07 & 42.03 & 44.97 & 47.00 & 44.02 \\
\hline 50 days & 33.17 & 35.00 & 43.30 & 43.43 & 38.73 & 50 days & 40.10 & 40.53 & 42.63 & 45.20 & 42.12 \\
\hline Mean & 41.98 & 44.41 & 47.45 & 48.33 & & Mean & 46.44 & 46.89 & 48.62 & 50.31 & \\
\hline \multicolumn{4}{|c|}{ L.S.D $0.05 \mathrm{~A}($ Treatments $)=$} & \multicolumn{2}{|c|}{0.51} & \multicolumn{4}{|c|}{ L.S.D $0.05 \mathrm{~A}($ Treatments $)=$} & \multicolumn{2}{|c|}{0.45} \\
\hline \multicolumn{4}{|c|}{ L.S.D 0.05 B(Period)= } & \multicolumn{2}{|c|}{0.63} & \multicolumn{4}{|c|}{ L.S.D 0.05 B(Period $)=$} & \multicolumn{2}{|c|}{0.56} \\
\hline \multicolumn{4}{|c|}{ L.S.D $0.05 \mathrm{AB}=$} & \multicolumn{2}{|c|}{1.25} & \multicolumn{4}{|c|}{ L.S.D $0.05 \mathrm{AB}=$} & \multicolumn{2}{|c|}{1.11} \\
\hline
\end{tabular}

\section{B- Chemical properties:}

1-Total soluble solids content (T.S.S\%):

Total soluble solids content in the stored Balady orange fruits as affected by $\mathrm{K}$ and SA treatments are shown in in Table 3. Generally, the obtained results took approximalaty the same tendency during both experimental seasons. T.S.S content significantly increased with extending the storage period and reaches its maximum values at the end of storage. Moreover the highest T.S.S percentage (15.10 and $15.00 \%)$ were recorded in the untreated fruits (control), while the lowest values were measured in the treated fruits with SA (13.67 and $13.83 \%$ ) during both 2015 and 2016 seasons ,respectively. This could be due to the higher water loss percentage of control fruits as compared with other treatments.

In addition significant differences were found between control and SA or SA+K during 2015 season, while all treatments gave a significant high content of T.S.S as compared with control fruits during 2016 season

These results are in line with (Baldwin et al., 1995), (Sabir et al., 2004), (Montanaro et al., 2006), (ElAnany et al.,2009) and (Ali et al., 2010).

Increasing T.S.S of citrus fruits according to potassium foliar spraying was proved by (Gill et al., 2005) in India working on Kinnow mandarin. Studies, illustrated that potassium foliar spraying did not effecton T.S.S. of citrus fruits (Miller et al., 1998). 
Table 3. Effect of potassium sulphate (48\%) and salicylic acid (4 mM/l) on TSS \% during storage periodat room temperature $\left(13 \pm 2 \mathrm{C}^{\circ}\right)$ on "Balady" orange fruits during 2015 and 2016 seasons

\begin{tabular}{|c|c|c|c|c|c|c|c|c|c|c|c|}
\hline \multicolumn{6}{|c|}{ Season 2015} & \multicolumn{6}{|c|}{ Season 2016} \\
\hline \multirow[t]{2}{*}{ Period } & \multicolumn{4}{|c|}{ Treatments } & \multirow[t]{2}{*}{ Mean } & \multirow[t]{2}{*}{ Period } & \multicolumn{4}{|c|}{ Treatments } & \multirow[t]{2}{*}{ Mean } \\
\hline & Control & $\mathrm{K}$ & SA & $\mathrm{SA}+\mathrm{K}$ & & & Control & $\mathrm{K}$ & SA & $\mathrm{SA}+\mathrm{K}$ & \\
\hline 0 date & 11.00 & 12.00 & 11.00 & 12.00 & 11.50 & 0 date & 11.67 & 13.00 & 11.67 & 13.00 & 12.33 \\
\hline 10 days & 12.50 & 12.50 & 11.33 & 12.17 & 12.13 & 10 days & 13.33 & 13.67 & 12.00 & 13.17 & \\
\hline 20 days & 12.83 & 12.83 & 12.17 & 12.83 & 12.67 & 20 days & 13.83 & 14.00 & 12.33 & 13.50 & 13.42 \\
\hline 30 days & 13.67 & 13.83 & 12.33 & 13.17 & 13.25 & 30 days & 14.33 & 14.67 & 13.00 & 13.83 & 13.96 \\
\hline 40 days & 14.33 & 14.67 & 12.83 & 13.33 & 13.79 & 40 days & 14.60 & 15.00 & 13.50 & 14.33 & 14.36 \\
\hline 50 days & 15.10 & 15.00 & 13.67 & 14.17 & 14.48 & 50 days & 15.00 & 15.37 & 13.83 & 14.50 & 14.68 \\
\hline Mean & 13.24 & 13.47 & 12.22 & 12.94 & & Mean & 13.79 & 14.28 & 12.72 & 13.72 & \\
\hline \multicolumn{4}{|c|}{ L.S.D $0.05 \mathrm{~A}($ Treatments $)=$} & \multicolumn{2}{|c|}{0.15} & \multicolumn{4}{|c|}{ L.S.D $0.05 \mathrm{~A}($ Treatments $)=$} & \multicolumn{2}{|c|}{0.19} \\
\hline \multicolumn{4}{|c|}{ L.S.D 0.05 B(Period $)=$} & \multicolumn{2}{|c|}{0.19} & \multicolumn{4}{|c|}{ L.S.D $0.05 \mathrm{~B}($ Period $)=$} & \multicolumn{2}{|c|}{0.23} \\
\hline \multicolumn{4}{|c|}{ L.S.D $0.05 \mathrm{AB}=$} & \multicolumn{2}{|c|}{0.38} & \multicolumn{4}{|c|}{ L.S.D $0.05 \mathrm{AB}=$} & \multicolumn{2}{|c|}{0.46} \\
\hline
\end{tabular}

\section{2- Acidity \%:}

It is known that the acidity percentage is gradually decreased with prolonging of storage period. Data in Table 4 showed the effect of potassium $(\mathrm{K})$ and salicylic acid (SA) on acidity $\%$ in the fruit of Balady orange. The obtained results indicated that same trend during both seasons was found, which the content of acidity gradually decreased with storage period progress and reached its minimum values at the end of storage.

Moreover, all treatments significantly increased the acidity content comparing with control, so the untreated fruits had the lowest values of acidity (0.967 and $0.950 \%)$ at the end of storage period during both 2015 and 2016 seasons, respectively.

On the other hand, the treated fruit with $(\mathrm{SA}+\mathrm{K})$ contained the highest acidity percentage $(1.080 \%)$ in the first season while the fruits treated with SA had the highest acidity content in the second one $(1.203 \%)$.

These results are in the same line with those obtained by (Willis et $a l ., 1998$ ) and (Yaman and Bayoin- dirli, 2002). Increasing acidity of citrus fruits, by foliar spraying with potassium, was reported by (Gill et al., 2005) and (Rattanpal et al., 2008) onKinnow mandarin, While, (Cicala and Catara, 1994) in Italy working on Tarocco orange and (Miller et al.,1998) in South Africa using Midknight Valeucia and Robyn navel orange, demonstrated that potassium foliar application did not affect on fruit acidity.

\section{3- TSS/Acid Ratio:}

It is known that the TSS/acid ratio is indicator for reaching the fruits to ripening stage. In general, with the prolonging of storage period the percentage of $\mathrm{TSS} \%$ is increased and the acidity $\%$ is decreased therefore the $\mathrm{TSS} /$ acid ratio is increased. Data in Table 5 illustrated that, at the end of storage in the both seasons the highest reduction of TSS/acid ratio was noted $\mathrm{inT}_{3}$ (12.66 and 11.43), respectively and the highest value was obtained by control (15.60 and 15.79), in the both seasons respectively and there were significant differences between all treatments and control in the two successive seasons. 
Table 4. Effect of potassium sulphate (48\%) and salicylic acid (4 mM) on Acidity $\%$ during storage period at room temperature $\left(13 \pm 2 \mathrm{C}^{\circ}\right)$ on "Balady" orange fruits during 2015 and 2016 seasons

\begin{tabular}{|c|c|c|c|c|c|c|c|c|c|c|c|}
\hline \multicolumn{6}{|c|}{ Season 2015} & \multicolumn{6}{|c|}{ Season 2016} \\
\hline \multirow{2}{*}{ Period } & \multicolumn{4}{|c|}{ Treatments } & \multirow{2}{*}{ Mean } & \multirow{2}{*}{ Period } & \multicolumn{4}{|c|}{ Treatments } & \multirow{2}{*}{ Mean } \\
\hline & Control & $\mathrm{K}$ & SA & $\mathrm{SA}+\mathrm{K}$ & & & Control & $\mathrm{K}$ & SA & $\mathrm{SA}+\mathrm{K}$ & \\
\hline 0 date & 1.313 & 1.310 & 1.350 & 1.353 & 1.332 & 0 date & 1.363 & 1.443 & 1.467 & 1.497 & 1.443 \\
\hline 10 days & 1.207 & 1.210 & 1.303 & 1.310 & 1.258 & 10 days & 1.267 & 1.387 & 1.417 & 1.433 & 1.376 \\
\hline 20 days & 1.127 & 1.130 & 1.237 & 1.240 & 1.183 & 20 days & 1.213 & 1.310 & 1.370 & 1.357 & 1.313 \\
\hline 30 days & 1.097 & 1.110 & 1.187 & 1.207 & 1.150 & 30 days & 1.117 & 1.220 & 1.327 & 1.287 & 1.238 \\
\hline 40 days & 1.003 & 1.050 & 1.127 & 1.183 & 1.091 & 40 days & 1.010 & 1.173 & 1.260 & 1.227 & 1.168 \\
\hline 50 days & 0.967 & 0.990 & 1.077 & 1.080 & 1.028 & 50 days & 0.950 & 1.087 & 1.203 & 1.153 & 1.098 \\
\hline Mean & 1.119 & 1.133 & 1.213 & 1.229 & & Mean & 1.153 & 1.270 & 1.341 & 1.326 & \\
\hline \multicolumn{4}{|c|}{ L.S.D $0.05 \mathrm{~A}($ Treatments $)=$} & \multicolumn{2}{|c|}{0.012} & \multicolumn{4}{|c|}{ L.S.D 0.05 A(Treatments $)=$} & \multicolumn{2}{|c|}{0.019} \\
\hline \multicolumn{4}{|c|}{ L.S.D 0.05 B $($ Period $)=$} & \multicolumn{2}{|c|}{0.015} & \multicolumn{4}{|c|}{ L.S.D $0.05 \mathrm{~B}($ Period $)=$} & \multicolumn{2}{|c|}{0.023} \\
\hline \multicolumn{4}{|c|}{ L.S.D $0.05 \mathrm{AB}=$} & \multicolumn{2}{|c|}{0.030} & \multicolumn{4}{|c|}{ L.S.D $0.05 \mathrm{AB}=$} & \multicolumn{2}{|c|}{0.047} \\
\hline
\end{tabular}

Table 5. Effect of potassium sulphate $(48 \%)$ and salicylic acid $(4 \mathrm{mM})$ on TSS/Acidity \% during storage period at room temperature $\left(13 \pm 2 \mathrm{C}^{\circ}\right)$ on "Balady" orange fruits during 2015 and 2016 seasons

\begin{tabular}{|c|c|c|c|c|c|c|c|c|c|c|c|}
\hline \multicolumn{6}{|c|}{ Season 2015} & \multicolumn{6}{|c|}{ Season 2016} \\
\hline \multirow{2}{*}{ Period } & \multicolumn{4}{|c|}{ Treatments } & \multirow{2}{*}{ Mean } & \multirow{2}{*}{ Period } & \multicolumn{4}{|c|}{ Treatments } & \multirow{2}{*}{ Mean } \\
\hline & Control & $\mathrm{K}$ & SA & $\mathrm{SA}+\mathrm{K}$ & & & Control & $\mathrm{K}$ & SA & $\mathrm{SA}+\mathrm{K}$ & \\
\hline 0 date & 8.33 & 9.13 & 8.11 & 8.80 & 8.59 & 0 date & 8.50 & 8.93 & 7.93 & 8.67 & 8.51 \\
\hline 10 days & 10.33 & .30 & 8.63 & 9.23 & 9.63 & 10 days & 10.47 & 83 & 8.43 & .17 & .48 \\
\hline 20 days & 11.40 & 11.33 & 9.80 & 10.33 & 10.72 & 20 days & 11.33 & 10.63 & 8.93 & 9.93 & 10.21 \\
\hline 30 days & 12.40 & 12.45 & 10.36 & 10.87 & 11.52 & 30 days & 12.82 & 12.00 & 9.73 & 10.73 & 11.32 \\
\hline 40 days & 14.27 & 13.93 & 11.37 & 11.25 & 12.71 & 40 days & 14.46 & 12.78 & 10.70 & 11.93 & 12.47 \\
\hline 50 days & 15.60 & 15.15 & 12.66 & 13.13 & 14.13 & 50 days & 15.79 & 14.15 & 11.43 & 12.58 & 13.49 \\
\hline Mean & 12.06 & 12.05 & 10.15 & 10.60 & & Mean & 12.23 & 11.39 & 9.53 & 10.50 & \\
\hline \multicolumn{4}{|c|}{ L.S.D $0.05 \mathrm{~A}($ Treatments $)=$} & \multicolumn{2}{|c|}{0.17} & \multicolumn{4}{|c|}{ L.S.D $0.05 \mathrm{~A}($ Treatments $)=$} & \multicolumn{2}{|c|}{0.22} \\
\hline \multicolumn{4}{|c|}{ L.S.D $0.05 \mathrm{~B}($ Period $)=$} & \multicolumn{2}{|c|}{0.21} & \multicolumn{4}{|c|}{ L.S.D 0.05 B (Period $)=$} & \multicolumn{2}{|c|}{0.27} \\
\hline \multicolumn{4}{|c|}{ L.S.D $0.05 \mathrm{AB}=$} & \multicolumn{2}{|c|}{0.41} & \multicolumn{4}{|c|}{ L.S.D $0.05 \mathrm{AB}=$} & \multicolumn{2}{|c|}{0.55} \\
\hline
\end{tabular}

\section{4- Ascorbic acid:}

The obtained results indicated thatduring storage periodthe ascorbic acid content of fruits gradually decreased with prolonging the storage period.

Data in Table 6 revealed thatthere were significant differences between the treatments and control in both successive seasons (2015 and 2016). At the end of storage period, the lowest value of ascorbic acid \% was found in control fruits (27.60 and 26.50) during both seasons, respectively.
Ascorbic acid reached to a highervalue in all treated fruits compared with control in the two seasons. The highest value of ascorbic acid was found in $_{3}$ treatment (44.80 and $40.87 \%$ ) in two seasons, respectively.

These results are in the same line withthe findings of (Ali et al, 2009) and (Ali, Eskandari et al, 2013)

(Ali and Gobran, 2002), (Gill et al., 2005), (Rattanpal et al., 2008) notified that foliar application of potassium increased vitamin $\mathrm{C}$ content of citrus fruits. 
Table 6. Effect of potassium sulphate $(48 \%)$ and salicylic acid $(4 \mathrm{mM} / \mathrm{l})$ on V.C $(\mathrm{mg} / 100 \mathrm{~mL})$ during storage period at room temperature $\left(13 \pm 2 \mathrm{C}^{\circ}\right)$ on "Balady" orange fruits during 2015 and 2016 seasons

\begin{tabular}{|c|c|c|c|c|c|c|c|c|c|c|c|}
\hline \multicolumn{6}{|c|}{ Season 2015} & \multicolumn{6}{|c|}{ Season 2016} \\
\hline \multirow{2}{*}{ Period } & \multicolumn{4}{|c|}{ Treatments } & \multirow{2}{*}{ Mean } & \multirow{2}{*}{ Period } & \multicolumn{4}{|c|}{ Treatments } & \multirow{2}{*}{ Mean } \\
\hline & Control & $\mathrm{K}$ & SA & $\mathrm{SA}+\mathrm{K}$ & & & Control & $\mathrm{K}$ & SA & $\mathrm{SA}+\mathrm{K}$ & \\
\hline 0 date & 52.70 & 53.40 & 52.70 & 53.70 & 53.13 & 0 date & 52.60 & 53.93 & 52.60 & 53.93 & 53.27 \\
\hline 10 days & 44.63 & 47.67 & 50.80 & 51.43 & 48.63 & 10 days & 44.70 & 50.07 & 50.33 & 51.60 & 49.18 \\
\hline 20 days & 42.27 & 45.50 & 48.73 & 49.93 & 46.61 & 20 days & 41.97 & 45.83 & 47.50 & 49.10 & 46.10 \\
\hline 30 days & 39.37 & 43.37 & 45.80 & 48.10 & 44.16 & 30 days & 38.67 & 42.67 & 46.50 & 45.77 & 43.40 \\
\hline 40 days & 37.50 & 40.03 & 43.73 & 46.13 & 41.85 & 40 days & 34.97 & 39.00 & 43.33 & 42.37 & 39.92 \\
\hline 50 days & 27.60 & 35.90 & 42.50 & 44.80 & 37.70 & 50 days & 26.50 & 32.20 & 40.77 & 40.87 & 35.08 \\
\hline Mean & 40.68 & 44.31 & 47.38 & 49.02 & & Mean & 39.90 & 43.95 & 46.84 & 47.27 & \\
\hline \multicolumn{4}{|c|}{ L.S.D $0.05 \mathrm{~A}($ Treatments $)=$} & \multicolumn{2}{|c|}{0.43} & \multicolumn{4}{|c|}{ L.S.D $0.05 \mathrm{~A}($ Treatments $)=$} & \multicolumn{2}{|c|}{0.38} \\
\hline \multicolumn{4}{|c|}{ L.S.D 0.05 B(Period) $=$} & \multicolumn{2}{|c|}{0.53} & \multicolumn{4}{|c|}{ L.S.D 0.05 B(Period $)=$} & \multicolumn{2}{|c|}{0.46} \\
\hline \multicolumn{4}{|c|}{ L.S.D $0.05 \mathrm{AB}=$} & \multicolumn{2}{|c|}{1.06} & \multicolumn{4}{|c|}{ L.S.D $0.05 \mathrm{AB}=$} & \multicolumn{2}{|c|}{0.93} \\
\hline
\end{tabular}

\section{Discussion:}

There is a correlation between weight $\operatorname{loss} \%$ and juice content $\%$. Increment of weight loss is indicator for decreasing of juice content $\%$ in the fruits during storage period. Water loss begins firstly from the peel then from the pulp of fruit. The time which takes for water loss or evaporation from fruit depends on the thickness of the fruit skin, the temperature and the length of storage period. The basic mechanism of weight loss from fresh vegetables and fruit is by respiration addition to that, vapor pressure at different locations also causes a weight reduction (Yaman and Bayoindirli, 2002).

The major problem for the fruits during storage period is the loss of water thus, the fruit could lose its quality (Ben-Yehoshua and Rodeo, 2003). Salicylic acid prolongs the storage period of orange fruits by decreasing both of the rate respiration and transpiration, ethylene biosynthesis, water loss and decay infection (Zheng and Zhang, 2004), (Ehsan et al., 2011). Salicylic acid is consid- ered a plant hormone that prevents ethylene biosynthesis, delays the senescence by inhibiting the conversion of ACC to ethylene and suppressing ACC oxides' activity, thereby, it causes the retard of fruit ripening. In addition, is contributory in local and systemic resistance to pathogens (Leslie and Romani, 1988), (Yan et al., 1998); (Han et al., 2003) and (Ozeker, 2005).

Total soluble solids (represents the main amount of soluble sugars), are the most important parameters that determine the quality of fruits and their ability to storage (Shwartz et al, 2009). Increasing of total soluble solids in treated fruits with SA due to reduce of ethylene production and that might be resulted in reducing enzyme activity and sucrosephosphate syntheses leading to reduce in sucrose synthesis. Furthermore, cell walls contain great values of polysaccharides, mainly pectin and cellulose, and are digested because of the activity of the cell wall degrading enzymes leading to a significant increase in TSS content (Baldwin et al., 
1995) (Sabir et al., 2004) (Montanaro et al., 2006), (El-Anany et al., 2009) and (Ali et al, 2010).

Generally, citrus fruits have abundant amounts of organic acids. The major organic acids in the juice are tartaric, oxalic, lactic, malic, citric and ascorbic. Of these six acids, citric acid considered the major acid of the total acid constituents of the juice followed by malic acid. The decreasing of acid contents during fruits storage was referred to the use of acids in the fruit as a source of respiration and energy therefor, the conversion of organic acids to form of sugar (Karadeniz, 2004).

The increment of TSS and the loss of the TA determine the ripening stage of the fruits as well as to estimate the fruit taste which is demonstrated mainly by the balance between sweetness and acidity. The mainly function of SA is delaying the fruit ripening during storage by decreasing of ethylene production (Kazemi et al., 2011) and also improving the fruit quality (Asghari and Aghdam, 2010). Furthermore, SA gives small effect on TSS for some nonclimacteric fruits during cold storage (Sayyari et al., 2009).

The values which resulted are due to the use of citric acid in the process of respiration of fruits. Then with the time passing the degradation of citric acid lead to increase TSS as structural formula of citric acid is similar to glucose therefore decrease in citric acid is correlated with increase in TSS/acid ratio so sugar contents had become higher than acids. (Manzano and Diaz, 2001).

The conserving of ascorbic acid $\%$ in fruits which were treated with SA due to the reducing of respiration process and water loss thus decreasing of oxidation of ascorbic acid content compared with the reducing rate of ascorbic acid in control where increase respiration process and there for increasing of oxidation of ascorbic acid. The results of this study were in line with (Ali et al, 2009) and (Ali, Eskandari et al, 2013).

The DPPH scavenging activity, flavonoids, total phenols, ascorbic acid and anthocyanins contents of the fruits were significantly increment by SA treatment may be due to the stimulationenzyme activity of Phenylalanine ammonia-lyase (PAL) and therefor triggering the phenylpropanoid-flavonoids pathways then, these explained that SA as a safe signaling molecule could promote nutritional quality and enhanced health promoting and properties of fruits (Tareen et al., 2012), (Dokhanieh et al., 2013).

(Gill et al., 2005) in India illustrated that foliar potassium applications significantly increased peel thickness of know mandarin fruits. In addition, using Valencia orange demonstrated that potassium increased peel thickness (Goepfert et al., 1987).

\section{References}

A.O.A.C. (1985). Association of Official Agricultural Chemists Official Methods of Analysis.

A.O.A.C. (1990). Association of Official Agriculture Chemist Official Methods of Analysis $9^{\text {th }}$ pp. 832 .

Achilea, O. (1998). Citrus and tomato quality is improved by optimized $\mathrm{K}$ nutrition. In: Improved Crop Quality by Nutrient Management. Anac, D. and P. Martin - prevel (eds). Kluwer Academic Publishers. PP: 19-22. 
Ali, A., Maqbool, M., Ramachandran, S., Alderson, P.G., (2010). Gum Arabic as a novel edible coating for enhancing shelf-life and improving postharvest quality of tomato (Solanumlycopersicun L.) fruit. Postharvest Biology and Technology. 58(1): 42-47.

Ali, B.A., Ziada, A., Blunden, G., (2009). Biology effects of Arabic gum: A review of some recent research. Food and chemical Toxicology. 47: 1-8.

Ali, E., Mokhtar, H., Mohammad, H.D., Sadegh, T., (2013). Studying effects of edible coatings of Arabic gum and olive oil on the storage life and maintain quality of postharvest Sweet Lemon (Citrus Lemontta). International Journal of Agriculture and Crop Sciences. IJACS/2014/7-4/207-213.

Ali, M.A. and Y.N. Gobran., (2002). Effect of soil moisture regimes and potassium application on growth, yield and fruit quality of Washington navel orange trees. Annals of Agricultural Science, Moshtoher. 40(3): 1669-1697.

Asghari, M., Aghdam, M.S., (2010). Impact of salicylic acid on postharvest physiology of horticultural crops.Trends Food Sci. Technol., 21: 502-509.

Baldwin, E.A., Niesperos, M.O., Shaw, P.E., Burns, J.K., (1995). Effect of coatings and prolonged storage conditions on fresh orange flavour volatiles, degrees brix and ascorbic acid levels. Journal of Agricultural and Food Chemistry 43 (5): 13211331.

Ben-Yehoshua, S., Rodov, V., (2003). Transpiration and water stress. In: Bartz JA, Brecht JK (eds) Postharvest physiology and pathology of vegetables, $2^{\text {nd }}$ edn. Marcel Dekker, Inc, New York., 111-159.
Chen, J., Wen, P., Kong, W., Pan, Q., Zhan, J., Li, J., Wan, S., Huang, W., (2006). Effect of salicylic acid on phenylpropanoids and phenylalanine ammonia-lyase in harvested grape berries. Postharvest Biol. Technol., 40: 64-7.

Chitarra, M.I.F., Chitarra, A.B., (2005). Postharvest of fruits and vegetables: physiology and handling. $2^{\text {nd }}$ ed. UFLA. Lavras, p. 785.

Cicala, A. and V. Catara (1994). Potassium fertilization effects on yield, fruit quality and mineral composition of leaves of Tarocco orange trees. Proceeding of the International Society of Citriculture: Volume 2. Cultural practices, diseases and their control: $7^{\text {th }}$ International Citrus congress, Acireale, Italy, 813 March, 1992-1994,618-620.

Del-Caro, A., Piga, A., Vacca,V., Agabbio, M., (2004). Changes of flavonoids, vitamin $\mathrm{C}$ and antioxidant capacity in minimally processed citrus segments and juices during storage. Food Chem. 84:99-105.

Dhuique-Mayer, C., Veyrat, C.C., Ollitrault, P., Curk, F., Amiot, M.J., (2005). Varietal and inter specific influence on micronutrient contents in citrus from the Mediterranean area. J. Agric. Food Chem., 53: 2140-2145.

Dokhanieh, A.Y., Aghdam, M.S., Rezapour Fard, J., Hassanpour, H., (2013). Postharvest salicylic acid treatment enhances antioxidant potential of cornelian cherry fruit. Scientia Horticulture., 154: 31-36.

Ehsan, R., Hassan, S., Akira, W., Davood, B., (2011). Effect of salicylic acid on storage life and postharvest quality of grape (Vitisvinifera L. cv. BidanehSefid) .J. Fac. Agr., Kyushu Univ., 56(2), 263269.

El-Anany, A., Hassan, M., Rehab, G.F.A., Ali, F.M., (2009). Effects 
of edible coatings on the shelf-life and quality of Anna apple (MalusdomesticaBorkh) during cold storage. Journal of Food Technology 7, 5-11.

FAO, (2014). FAOSTAT Database Results, online access $12^{\text {th }}$ February (2014).

Gill, P.S.; S.N. Singh and A.S. Dhatt (2005). Effect of foliar application of $\mathrm{K}$ and $\mathrm{N}$ fertilizers on fruit quality of Kinnow mandarin. Indian Journal of Horticulture. 62(3):282284.

Goepfert, C.F.; E.L.S. de Saldanha and O. de M.porto (1987). The response of Valencia orange (Citrus sinensis, Osb.) to fertilizer levels, average of eight harvests. AgronomiaSulriograndense. 23(2): 203-215.

Hafez-Omaima, M., Haggag, K.H.E., (2007). Quality improvement and storability of apple cv. Anna by pre-harvest Applications of Boric acid and Calcium Chloride J. Agric. \& Biol. Sci., 2(3): 176-183.

Han, T.,Wang, Y., Li, L., Ge, X., (2003). Effect of exogenous salicylic acid on postharvest physiology of peaches. In: R.K. Prange (Editor), XXVI Inter-national Horticultural Congress: Issues and Advances in Postharvest Horticulture, Canada, 12 December, 2003. Acta Hort, $628 \mathrm{pp}$.

Hayat, Q., Hayat, S., Irfan, M., Ahmad, A., (2010). Effect of exogenous salicylic acid under changing environment. A review. Environmental and Experimental Botany., 68: 1425.

Hsiao, T.C. and Lauchli, A., (1986). Role of potassium in plant-water relations. V.2, pp. 281-312. In: Advances in Plant Nutrition. (Eds. B. Tinker and A.Lauchli.) Praeger Scientific, New York.
Huang, R, Xia, R., Lu, Y., Hu, L., and $\mathrm{Xu}, \mathrm{Y}$., (2008). Effect of preharvest salicylic acid sprays treatment on post-harvest antioxidant in the pulp and peel of 'Cara cara' navel orange (Citrus sinenisis L. Osbeck). Journal of the Science of Food and Agriculture., 88:229236.

Karadeniz, F., (2004). Main organic acid distribution of authentic citrus juices in Turkey. Turk. J. Agric. For. 28: 267-271.

Kazemi, M., Aran, M., Zamani, S., (2011). Effect of calcium chloride and salicylic acid treatment on quality characteristics of kiwifruit (Actinidiadeliciosa cv. Hayward) during storage. American Journal of Plant Physiology., 6: 183-189.

Lavon, R.; I.Horesh; S.Shapchiski; E.Mohel and N. Zur., (1995). Influence of foliar spray with monopotassium phosphate (MKP) on the yield, fruit size and fruit quality of Star-Ruby grapefruit. AlonHanotea. 49(4):172-176.

Leslie, C. A., Romani, R. J., (1988). Inhibition of ethylene biosynthesis by salicylic acid. Plant Physiol., 88:833-837. M.Sc., Thesis, Punjab Agricultural University, Ludhiana, India.

Maksoud, M.A.; M.M.S. Saleh; L.F. Haggag and B.N.Boutros., (2003). Effects of iron and potassium fertilization on Balady mandarin trees grown in calcareous soil. Annals of Agricultural Science (Cairo). 48 (2):741-746.

Manzano, J.E., Diaz, A., (2001). Effect of storage time, temperature and wax coating on the quality of fruits of 'Valencia' orange (Citrus sinensis L.). Proc. Int'l. Soc. Tropical Hort. 44: 24-29.

Miller, J.; J. maritz and P.Bird (1998). Could potassium be used to improve Midknight Valencia and 
Robyn Navel. Neltropika Bulletin. 302:32-33.

Montanaro, G., Dichio, G., Xiloyannis, B.C., Celano, G., (2006). Light influences transpiration and calcium accumulation in fruit of kiwifruit plants (Actinidiadeliciosa var. deiciosa). Plants Science, 170: 520-527.

Ozeker, E., (2005). Salicylic acid and its effects on plants. E.U. Faculty of Agriculture J., 42 (1): 213-223 (Tr).

Park, H.J., (1999). Development of advanced edible coatings for fruits. Trends Food Sci. Technol. 10, 254-260.

Petracek, P.D., Dou, H., and Pao, S., (1998). The influence of applied waxes on postharvest physiological behavior and pitting of grapefruit. Postharvest Biol. Technol. 14,99-106.

Rattanpal, H.S.; S.Rani and H.S. Dhaliwal (2008). Effect of potassium and 2,4-D on yield and fruit quality of Kinnow mandarin. Environment and Ecology. 26(2):709-715.

Sabir, M.S., Shah, S.Z.A., Afzal, A., (2004). Effect of chemical treatment, wax coating, oil dipping and different wrapping materials on physio-chemical characteristics and storage behavior of apple (MalusdomesticaBorkh). Pakistan Journal of Nutrition 3 (2): 122127.

Sakhale, B.K., Kapse, B.M., (2012). Studies on shelf life extension of sweet oranges (Citrus sinensis L.). International Food Research Journal 19 (2): 779-781.

Sayyari, M., Babalar, M., Kalantari, S., Serrano, M., Valero, D., (2009). Effect of salicylic acid treatment on reducing chilling injury in stored pomegranates. Postharvest Biol. Technol., 53: 152-154.
Scotter, M. J., Roberts, D. P. T., Wilson, L. A., Howard, F. A. C., Davis, J., Mansell, N., (2007). Free salicylic acid and acetyl salicylic acid content of foods using gas chromatography-mass spectrometry. Food Chem., 105: 273-279.

Shein, N.N., Jaroenkit, T., Ussahatanonta, S., Jarassamrit, N., (2008). Effect of wax coating on the postharvest quality of 'Sai Nam Peung' mandarin orange (Citrus reticulata Blanco). Agricultural Science Journal 39 (3): 13-16.

Shwartz, E., Glazer, L., Bar-Yaakov, L., Martityaho, L., Bar-Ilan, I., (2009). Changes in chemical constituents during the maturation and ripening of two commercially important pomegranate accessions. Food Chemistry, 115: 965-973.

Snedecor, G.W. and Cochran, W.G. (1989). Statistical Methods, Eighth Edition, Iowa State University Press.

Srivastava, M.K., Dwivedi, U.N., (2000). Ripening of banana fruit by salicylic acid. Plant Science., 158: 87-96.

Tareen, M.J., Abbasi, N.A., Hafiz, I.A., (2012). Postharvest application of salicylic acid enhanced antioxidant enzyme activity and maintained quality of peach cv. Flordaking fruit during storage. ScientiaHorticulturae., 142: 221- 228.

Wills, R. B.H., Mc-Glasson, B., Graham, D., Joyce, D., (1998). Postharvest: An Introduction to the Physiology and Handling of Fruits, Vegetables and Ornamentals. $4^{\text {th }}$ ed. UNSW Press.

Wu, T., Guan, Y., and Ye, J., (2007). Determination of flavonoids and ascorbic acid in grapefruit peel and juice by capillary electrophoresis with electrochemical detection. Food Chem. 100:1573-1579. 
Yaman, O., Bayoindirli, L., (2002). Effects of an edible coating and cold storage on shelf-life and quality of cherries. Lebnsm.-Wiss. Und. Technol., 35: 46-150.

Yan T., Shen JG., Liu C D. (1998). Effects of salicylic acid on ripening fruits. Chin. Bull. Bot.,15 (3): 6164.
Zhang, Y., Kunsong, C., Zhang, S., and Ferguson, I., (2003). The role of salicylic acid in postharvest ripening of kiwi fruit. Postharvest Biol., Tec. 28(1):67-74.

Zheng, Y., Zhang, Q., (2004). Effects of polyamines and salicylic acid postharvest storage of 'Ponkan' mandarin. Acta Horticulturae., 632: 317-320. 
تأثير معاملات ما قبل وبعد الحصاد على قابلية ثمار البرتقال البلدي للتخزين

طلعت كامل المهدى ، احمد مخلص السيسى، مها محمد عبد السلام ، فاطمه عبد الحكيم اسماعيل قسم الفاكهة - كلية الزراعة - جامعة أسيوط

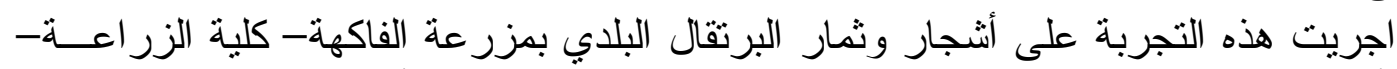

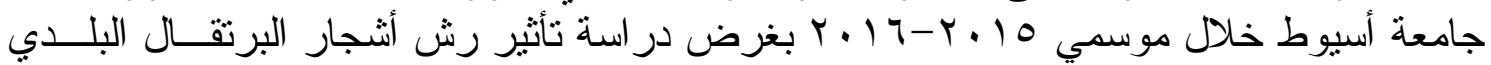

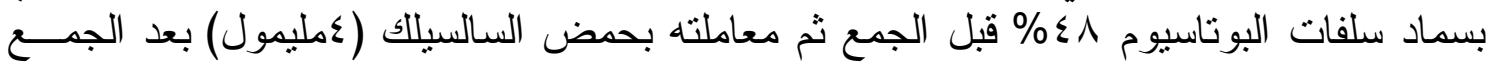

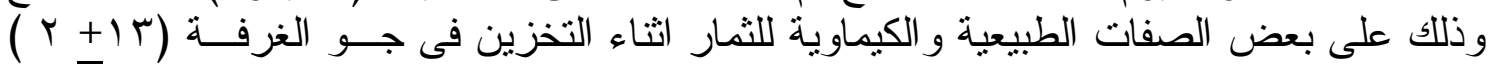

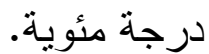

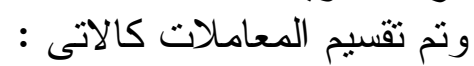

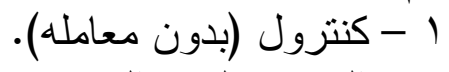

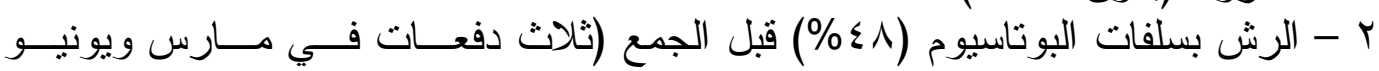
و أغسطس). r - الغمس في حمض سالسيلك (عليمول/ التر ) فى المعمل بعد الجمع.

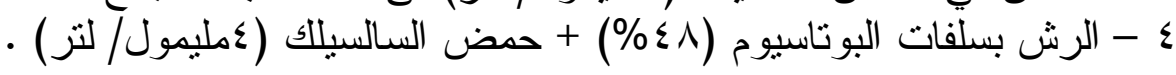

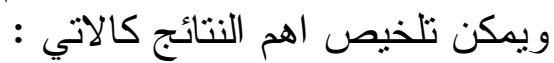

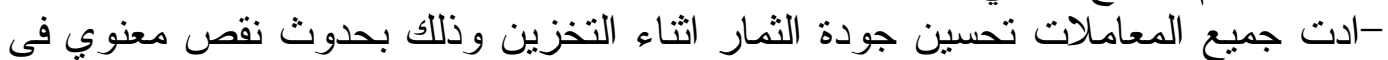

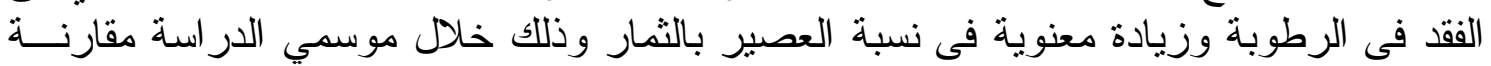
- ادت المعاملات بحمض السالسيلك منفردا او بالإضافة الى سلفات البوتاسيوم الى زيــادة

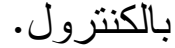

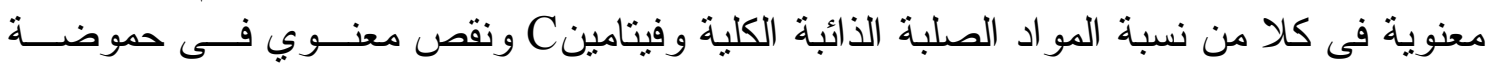
الثمار اثثاء التخزين خلال موسمي الدراسة. 